\title{
ROLE OF THE MEDIA AS A PRIME TOOL TO TACKLE RURAL POVERTY IN MEGHALAYA, INDIA
}

\section{S MAXWELL LYNGDOH ${ }^{1}$ \& SAMUEL WILSON MESHACK ${ }^{2}$}

${ }^{I}$ Associate Professor, Department of Social Work, Martin Luther Christian University, Shillong, Meghalaya, India

${ }^{2}$ President, World Association for Christian Communication (WACC) and

Professor of Communication @ Hindustan Bible Institute affiliated to MLCU, India

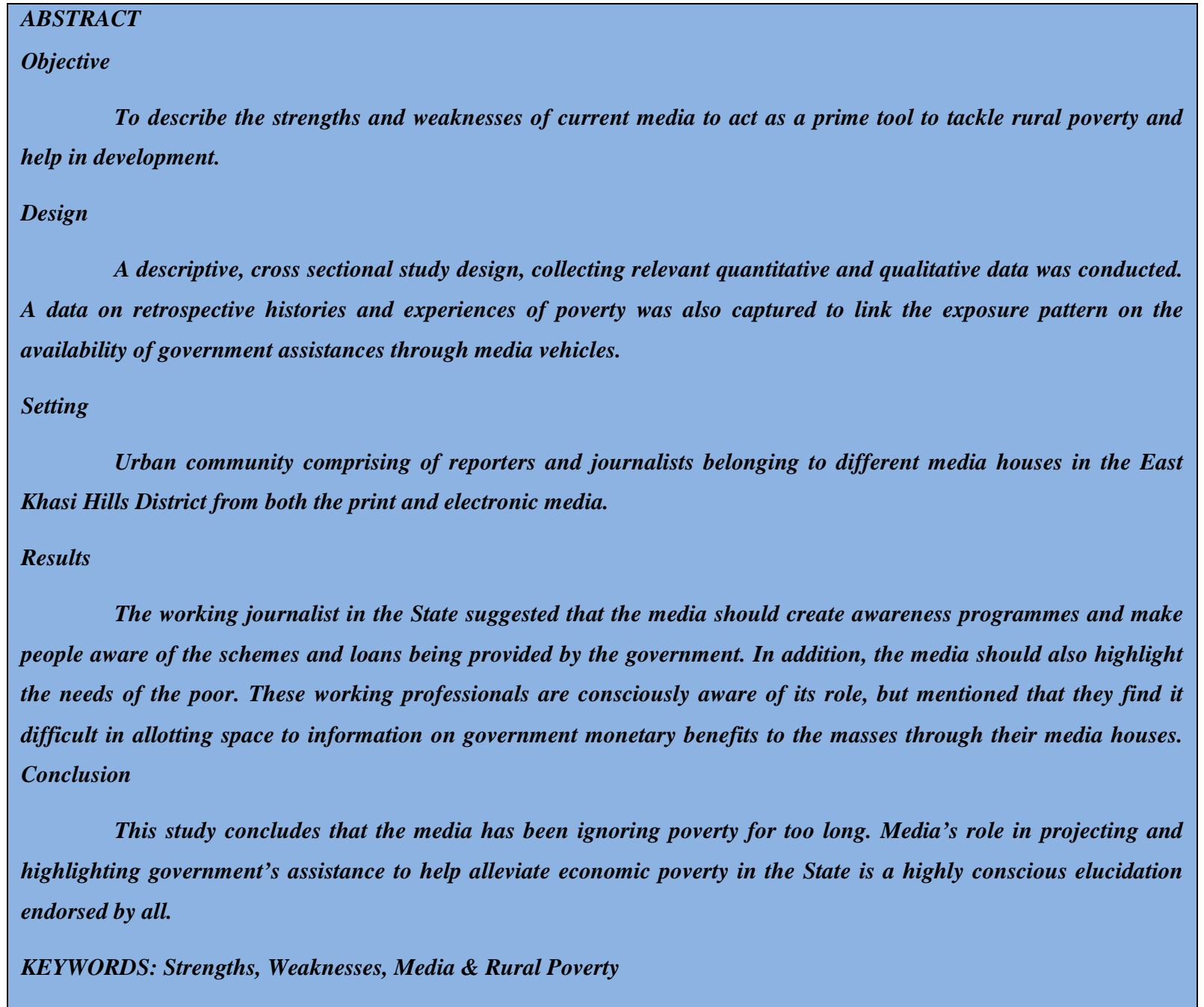

Received: Sep 03, 2017; Accepted: Sep 18, 2017; Published: Sep 28, 2017; Paper Id.: IJCMSOCT20175

\section{INTRODUCTION}

Meghalaya came into existence in the year 1972 after it got its separate statehood. "It attained subautonomous status in 1969 and that of a full State of the Indian Union in 1972" (Gopalakrishnan, 1995). In 2013, the State has been added with four more new districts making it a total of eleven districts. Meghalaya is one of the smallest States in India and the third biggest State in the North Eastern Region. It is predominantly a tribal, State 
(Nayak \& Thomas, 2007). Nayak and Thomas (2007) further mentioned that the State lagged in per capita SDP (State Domestic Product), rural and male literacy, rural poverty and urban infant mortality.

Poverty has been part and parcel of Meghalaya since it got its separate State. Development usually takes place at a faster rate for States that could function autonomously as independent States, but the case is different in Meghalaya where poverty still exists after so many years of its separate statehood. Though a few scholars have tried to study and analyze the situation of Meghalaya in the context of poverty, but have only been able to identify only a few of its causes. Thomas (2004) identifies the lack of technological innovations is also one of the reasons for the economic backwardness of the State. He says that, the State has virtually no industrial base despite being rich in minerals and scenic beauty, the latter being an economic resource vested in the hands of the entire community. It may be observed, that the causes of poverty could include the inability of the people to improve in animal husbandry, poor crop cultivation due to traditional methods of cultivation. The hilly areas require not only different technologies of cultivation, but also different suitable crops, this in turn has added to the factors of low land, labor and capital productivities.

Thomas (2004) said it is heartening to observe that the net income generated per hectare of gross cropped area is higher in the state, as compared to other more advanced states in the country. This is perhaps due to low adoption of new capital intensive seed-water, fertilizer technology in the state, resulting in a low cost of cultivation. This quoting, however reflects the ability of the people in rural Meghalaya to sustain their livelihood. Yet, there are many other factors that add to poverty in the state as Thomas again writes the incidence of unemployment (including underemployment) indicates a high incidence of poverty in the State.

According to the 2001 Census, the state had a population of 23.6 lakhs, which was about 6.0 percent of the total population of the country. It had a population density of 103 persons per sq.km, a sex ratio of 975 and a literacy rate of $63.3 \%$. About $19.6 \%$ of the population lived in urban areas (My India: History of Meghalaya, 2012). Although, the state has mainly an agricultural economy, and nearly 63 percent of her work force engaged in agriculture, its contribution to SDP, (State Domestic Product) was only 33\% as against 55\% of the tertiary sector. The extent of industrialization had been very low and slow in the State. The growth of per capita net SDP in the last decade was quite low, and it stood at Rs. 9003/- in 2000 at 1993-94 (constant) prices when 34\%of people were below the poverty line (Nayak \& Thomas, 2007).

The Government of Meghalaya conducted two censuses of the people living below the poverty line in 1991-92 and 1998, and estimated that the number was $48.9 \%$ in 1991-92 but has increased to $54.5 \%$ in 1998 . The gender wise break up of poor people shows a marginally higher number of poor women, as compared to men below the poverty line (Saxena, 2003). Yadav (2014) states that since the early 1950s, the Government has initiated, sustained, and refined various planning schemes to help the poor attain self sufficiency in food production. The schemes were however not very successful, because the rate of poverty reduction lags behind the rapid population growth rate.

In India, poverty eradication is one of the major objectives of planned development. The magnitude of the problem is still quite staggering. Thirty six percent of the Indian population was below the poverty line (BPL) in 1993-94, the latest year for which the data are available and the absolute number of poor was 320 million, out of which 244 million (37 per cent of the rural population) lived in rural areas (Poverty Alleviation in Rural India: Programs and Strategy, 2002). A news item in Solomon Star, on the "Role of news media in poverty reduction efforts" (2011), reads "Many families suffer from generational poverty, and with no hope or end in sight, young people are being lured into prostitution or drug trafficking". It further mentions, "The media is an important player - studies show that government and public response to 
poverty depends on how media frames the issue. Given the media's societal responsibilities, poverty should be at the top of its reporting agenda".

The mass media in a country like the USA, where the illiteracy is marginal, do run some programs (Sesame Street has been an often cited example among TV serials) of adult literacy and social education. These are for the benefit of immigrant labourers and of the poor among blacks (Raghavan, 2005). A new report by Panos London (2007), calls for greater involvement of the media in the efforts to tackle poverty. As the midpoint for achieving the Millennium Development Goals (MDGs) by 2015 is reached, and with the progress being in serious doubt, the time has come to recognize and support the potentially crucial contribution of the mass media on efforts to reduce poverty.

The Ninth Five Year Plan saw the implementations of many programmes and strategies to help alleviate poverty in rural India. A case in Andra Pradesh under, the special scheme for Development of Women and Children in Rural Areas (DWCRA), witnessed the use of media vehicles to create awareness and contributed to the process of social mobilisation (Poverty Alleviation in Rural India: Programmes and Strategy, 2002)

While the media is being examined as a tool to educate, it is also seen as an instrument of awareness. A news item in a newspaper reports that the rural people unaware of Central Schemes (The Shillong Times, 2011). This report reflects the government's lack of conducting awareness campaigns on the various centrally-sponsored schemes, which leaves many people in the dark, especially those living in the rural areas of the State. Another report mentions that poverty is up in Meghalaya and despite all tall talks of development, level of poverty in North Eastern states, including Meghalaya has increased, even though the same has declined in the rest of the country (The Shillong Times, 2012). According to the Planning Commission Report the States, which included Assam, Meghalaya, Manipur, Mizoram and Nagaland, poverty has increased in 2009-2010 (Planning Commission, 2014). This is perhaps one of the reasons why the media were questioned in an article "The media as a watchdog, Is anyone watching poverty?". The media were alleged that it is supposed to provide infotainment, if not pure entertainment, and is happy enough with the present situation (Joseph, 2011).

A large section of the Indian media (particularly the electronic media) does not serve the interest of the people; in fact, some of it is positively anti-people (Katju, 2011). The media often divert the attention of the people from the real issues to non issues. The real issues in India are socio-economic, the terrible poverty in which $80 \%$ of our people are living, the massive unemployment, the price rise, lack of medical care, education, and backward social practices like honour killing and caste oppression and religious fundamentalism etc,. There is no point expecting anything more or better from the media, especially commercial media, because they are run by business enterprises pursuing profits, not trying to improve society. Large sections of the public seem to accept this as inevitable and even unquestionable (Joseph, 2011).

However, in underdeveloped countries such as India the media have a great responsibility to fight backward ideas such as casteism and communalism, and help the people in their struggle against poverty and other social evils (Katju, 2008). "Society is influenced by media in so many ways. It is the media for the masses that helps them to get information about a lot of things and also to form opinions and make judgments regarding various issues" Shakeel (2012), and "if the media identifies its responsibility and work sincerely and honestly then it can serve as a great force in building the nation". Meshack (2011), on a similar discussion observed that the media has increasingly been playing the role once played by family, community, religion and formal education: not only disseminating information and knowledge, but also shaping values and norms, moulding attitudes and behaviour, and influencing the very process of living. 
This study aimed to look into the strengths and weaknesses of the current media and how it can act as a tool to tackle rural poverty, and help in development, by disseminating the information to the right people and at the right time.

\section{METHODS}

The methodology chosen for this research should therefore be capable of describing these linkages and their validity, as well as assist in formulating future strategies and recommendations for the reduction of poverty for the rural masses. In doing so, a mixture of both Qualitative research and Quantitative research approaches is adopted for this study. This research, carried out a descriptive, cross sectional study design, collecting relevant Quantitative and Qualitative data, as well as capturing some retrospective histories and experiences of poverty. Suitable sampling methods and appropriate data gathering tools were then developed. Necessary permissions and consent were obtained and all ethical norms were adequately addressed.

The research design is to choose reporters and journalists belonging to different media houses in the East Khasi Hills District from both the print and electronic media. The media houses with maximum number of existing in the region were considered. Dialect formed a major component. This is one prime reason why the vernacular and English medium of the media was both taken for this study. Four Khasi Dailies and four English Dailies were chosen as respondents from the print media, and similarly, four Khasi news channels and four English news channels were selected representing the electronic media. These samples were purposefully chosen to get a $100 \%$ representation of all the media houses functioning within the district. Table 1 and Table 2 highlights the samples selected.

Table 1

\begin{tabular}{|c|l|l|l|}
\hline Sl. No. & \multicolumn{1}{|c|}{ Organization } & \multicolumn{1}{|c|}{ Respondent } & Language \\
\hline 1. & The Shillong Times & Reporter & English \\
\hline 2. & Meghalaya Times & Reporter & English \\
\hline 3. & Mawphor Today & Reporter & English \\
\hline 4. & Meghalaya Guardian & Reporter & English \\
\hline 5. & Dongmusa & Reporter & Khasi \\
\hline 6. & U Rupang & Reporter & Khasi \\
\hline 7. & U Peitngor & Reporter & Khasi \\
\hline 8. & U Nongsain Hima & Reporter & Khasi \\
\hline
\end{tabular}

Table 2

\begin{tabular}{|c|l|l|l|}
\hline Sl. No. & \multicolumn{1}{|c|}{ Organization } & \multicolumn{1}{c|}{ Respondent } & \multicolumn{1}{c|}{ Language } \\
\hline 1. & DDK & Programme Executive & English \\
\hline 2. & FM 93.5 & Programme Executive & English \\
\hline 3. & Media Plus & Producer & English \\
\hline 4. & Net Vision & Producer & English \\
\hline 5. & Ri Khasi Channel & Producer & Khasi \\
\hline 6. & PCN & Producer & Khasi \\
\hline 7. & T7 & Producer & Khasi \\
\hline 8. & AIR & Programme Executive & Khasi \\
\hline
\end{tabular}

Data collection was initiated. The list of print and electronic media was collected from the Directorate of Information and Public Relations, Government of Meghalaya. Of these, only those print and electronic media functioning in the East Khasi Hills District was considered taking a proper minimum sample size. Prior permission of letters was forwarded before seeking appointments to conduct interviews with the journalist and reporters. All the respondents were briefed on the purpose of the interview. Free and frank responses were encouraged and the respondents were also told to 
give suggestions if any. The questions were primarily designed to seek a feedback on the strength and weaknesses of the media in addressing poverty in our rural Meghalaya. Here also, the timing of the entire interview to take place was prolonging from the actual scheduled time, as the researcher had to wait for the convenient time and place of the respondents who are practicing journalist, for the interview to take place.

\section{Ethical Issues}

Approval for the study was obtained from the University Research Ethics Committee of the University. Informed consent was taken from the media houses in the East Khasi Hills District, from both the print and electronic media, comprising of reporters and journalists.

\section{RESULTS}

The objective of this research is to describe the strengths and weaknesses of current media to act as a prime tool to tackle rural poverty and help in bringing in social development. This section presents responses on the findings and feedbacks from 16 media houses belonging to both print and electronic media in Shillong.

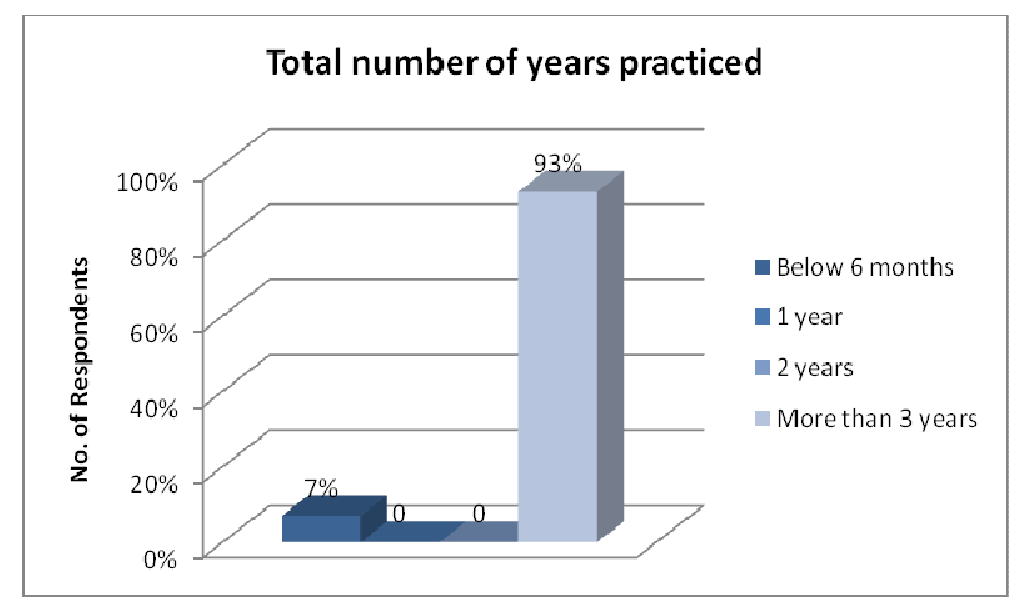

Figure I

Figure I highlight the number of years practiced by the present working journalist in different media houses in the State. A maximum portion of the respondents i.e. $93 \%$ says that they have been working for more than three years, while only $7 \%$ says that they have been practicing below 6 months.

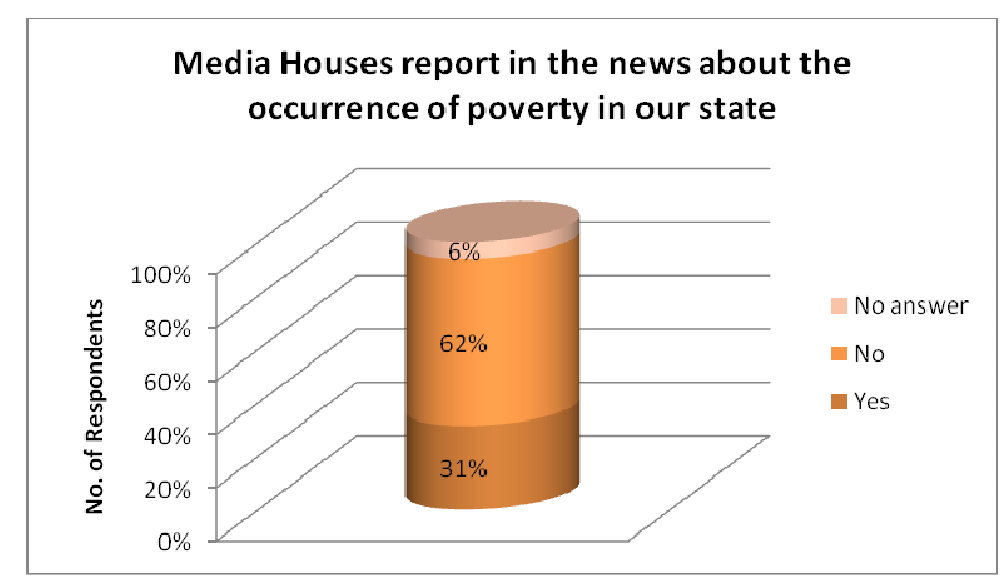

Figure II 
Figure II reflects the reporting of news about the occurrence of poverty in our State. $62 \%$ of the respondents said that they do not report such news at all. $31 \%$ responded to be reporting such news and the other $6 \%$ did not respond.

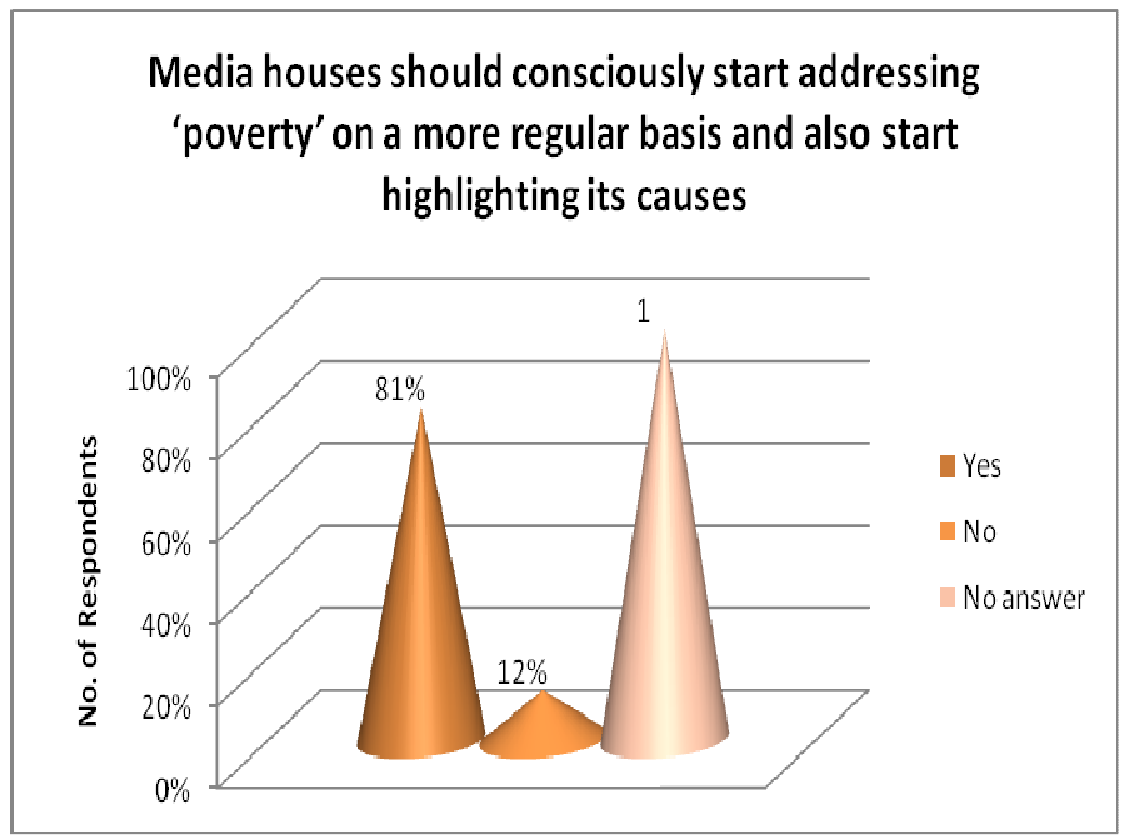

Figure III

Figure III shows the agreement of the practicing media persons to consciously start addressing poverty on a more regular basis and also start highlighting its causes. Maximum of the respondents said that we should do so in which $81 \%$ of them responded yes. $13 \%$ did not agree or felt it is still not very relevant and a criteria yet. The remaining $1 \%$ did not respond.

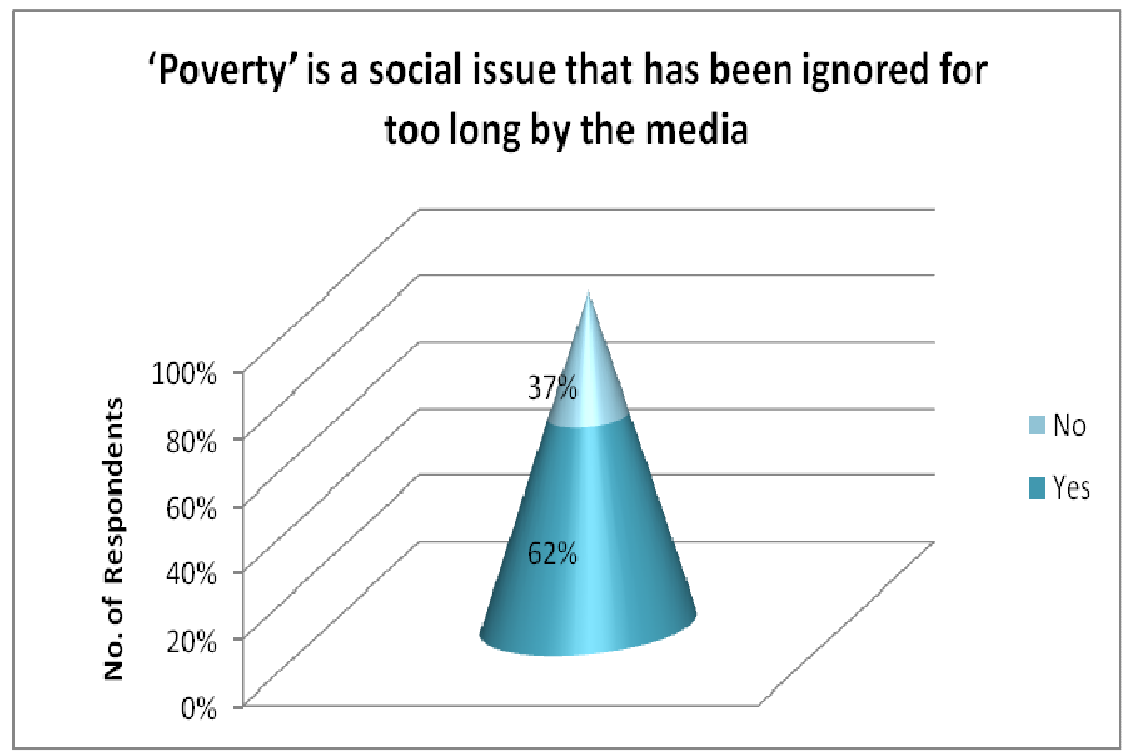

Figure IV

Figure IV reflects the agreement of the respondents that 'poverty' has been ignored for too long by the media. 62 $\%$ of the respondents agree while the other $37 \%$ disagree so. 


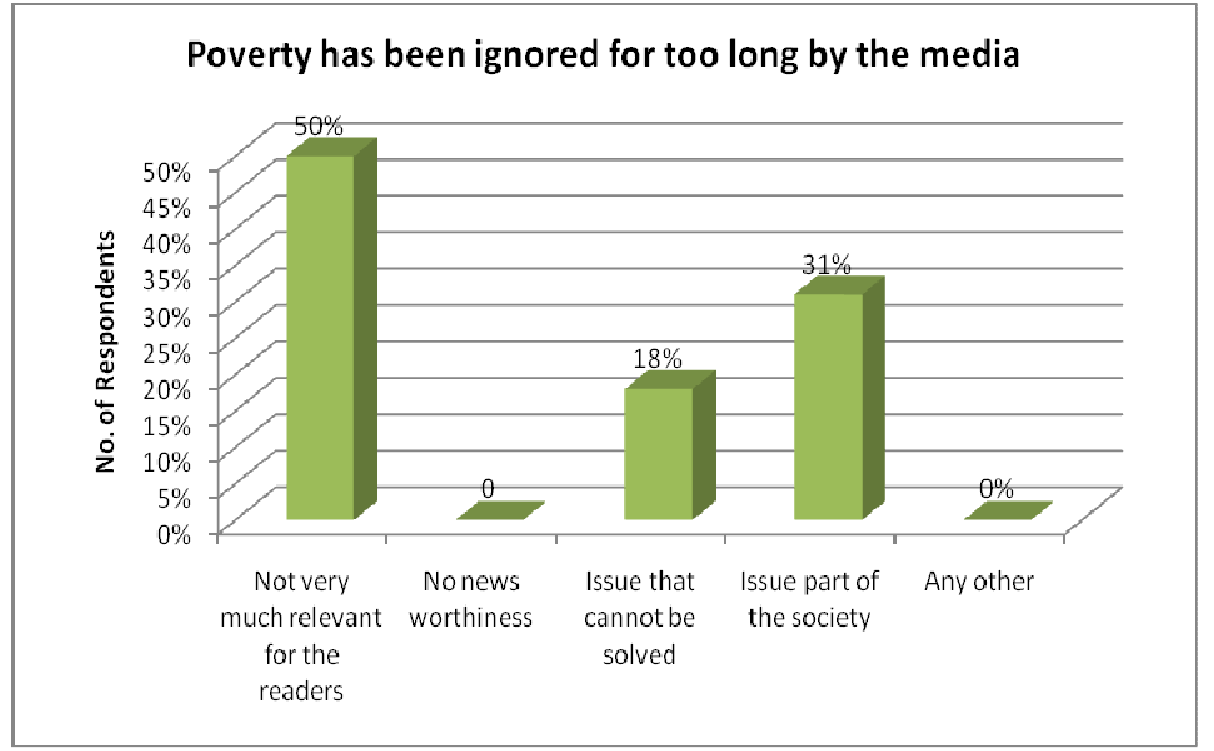

Figure V

Figure V shows the views of the respondents in regard to the ignorance of media towards 'poverty'. $50 \%$ say that news on poverty issues are not very much relevant for the readers. $18 \%$ say that it is pointless to report such events, as they are issues that cannot be solved while, $31 \%$ of the respondents believes that issues on poverty are just a part of the society that does not need a special reporting.

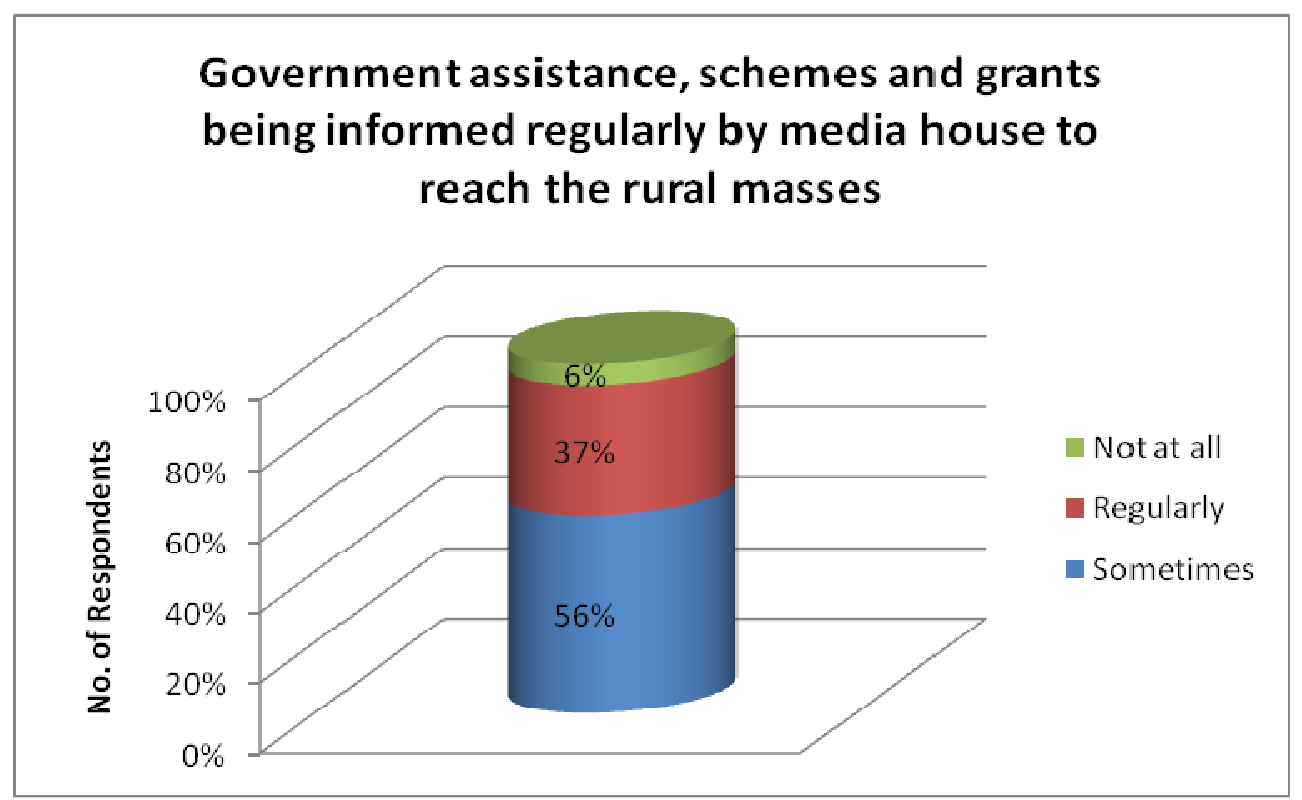

Figure VI

Figure VI shows the frequency of information that the different media house projects. $56 \%$ say that the availability of government assistance, schemes and grants are being informed by the media and it reaches the rural masses sometimes. $37 \%$ say that such information reaches the masses regularly, while $6 \%$ says that no such information reaches the masses through them at all. 


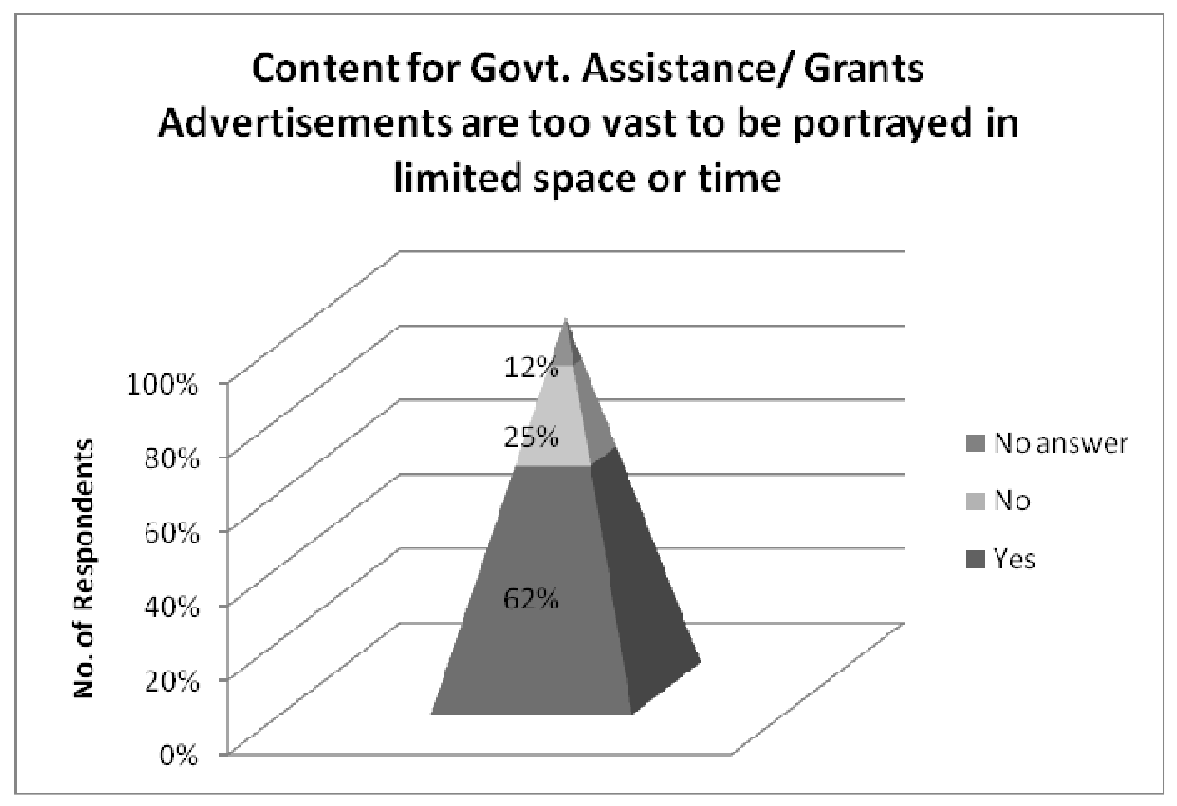

Figure VII

Figure VII shows the expression of the respondents of various media houses in the State of their opinion of how much space advertisements on government assistance and grants occupies. $62 \%$ say that such ads do occupy a lot of space in the slot that they have allotted to them. A response of $25 \%$ says that such ads do not occupy much space on these media vehicles. The other $12 \%$ did not respond.

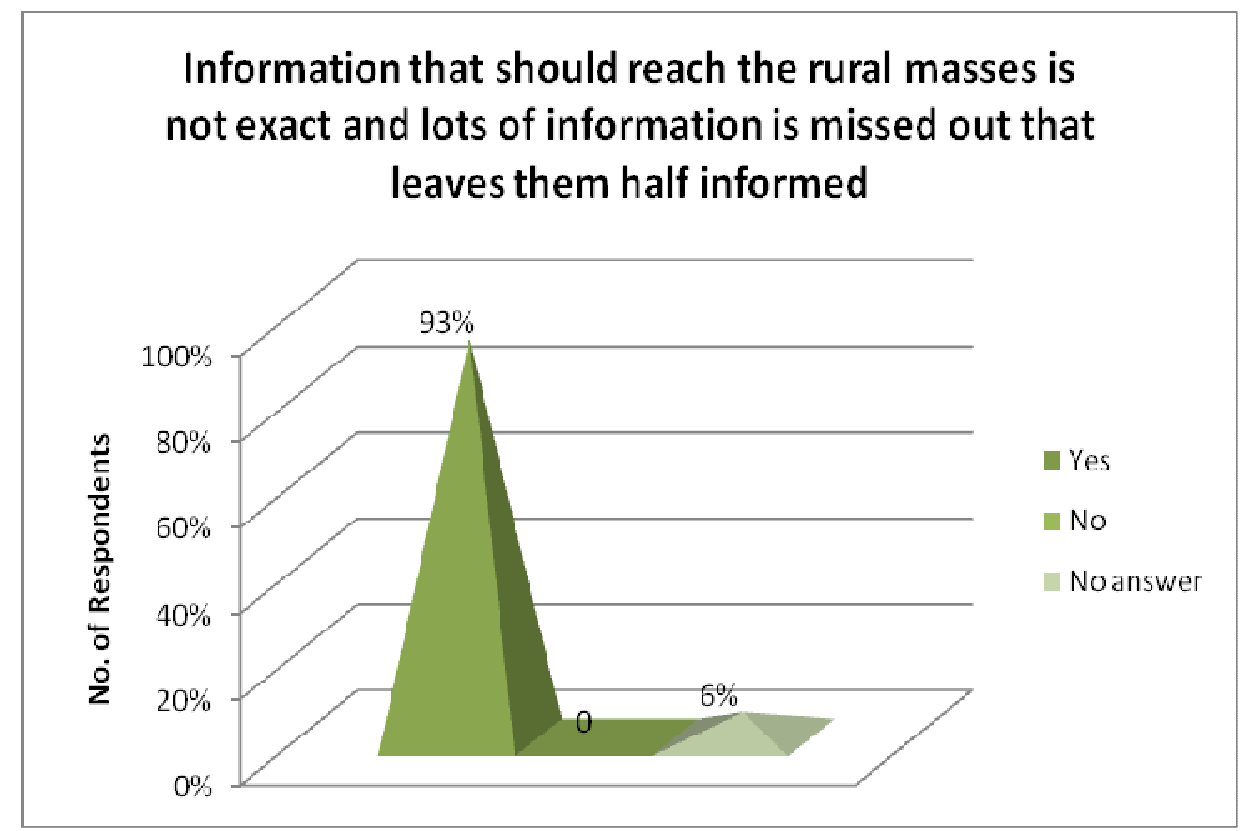

Figure VIII

Figure VIII reflects the opinion of the respondents in which they believe that a lot of information that should reach the rural masses is not exact and lots of information is missed out that leaves them half informed. A maximum of $93 \%$ agreed that information is missing before it actually reaches the masses. A minor of $6 \%$ other did not respond. 


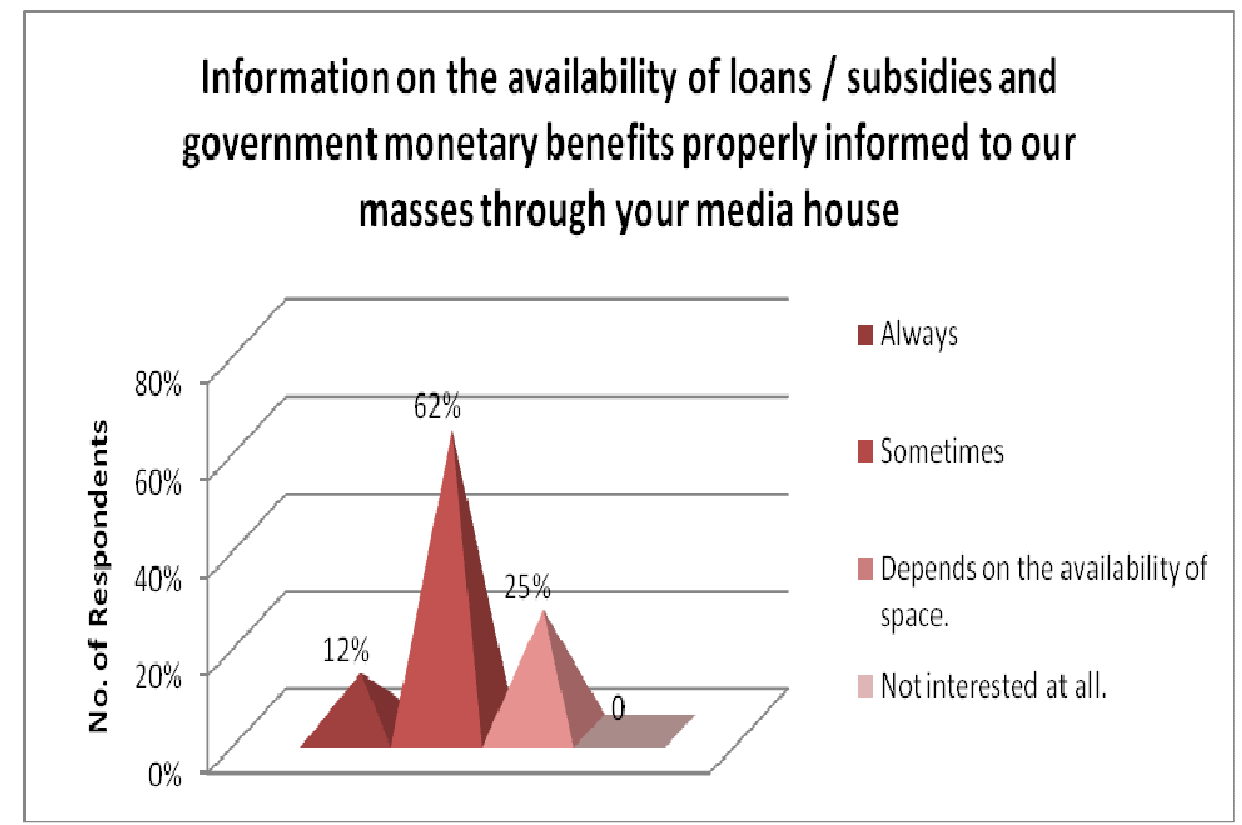

Figure IX

Figure IX shows the involvement of the media houses in informing the availability of loans / subsidies and government monetary benefits to the masses. $12 \%$ say that their media houses always keep the mass update and informed through their media vehicles. $62 \%$ of the respondents say that they do it only sometimes, while $25 \%$ others says they only give such ads based on the availability of space.

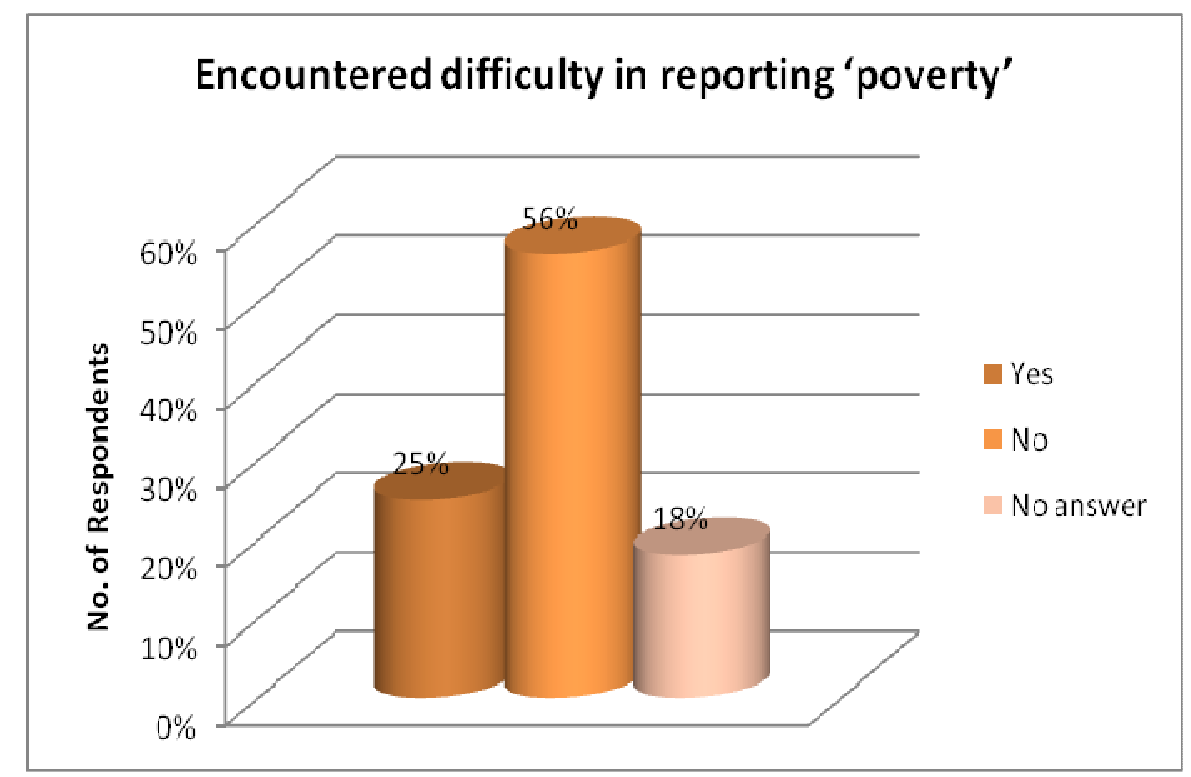

Figure $\mathbf{X}$

Figure $\mathrm{X}$ shows the response of the media persons while filing news reporting poverty. $25 \%$ say that they do encounter problems while filing such stories. $56 \%$ say they do not encounter much difficulty while filing stories on poverty while, $18 \%$ others did not respond. 


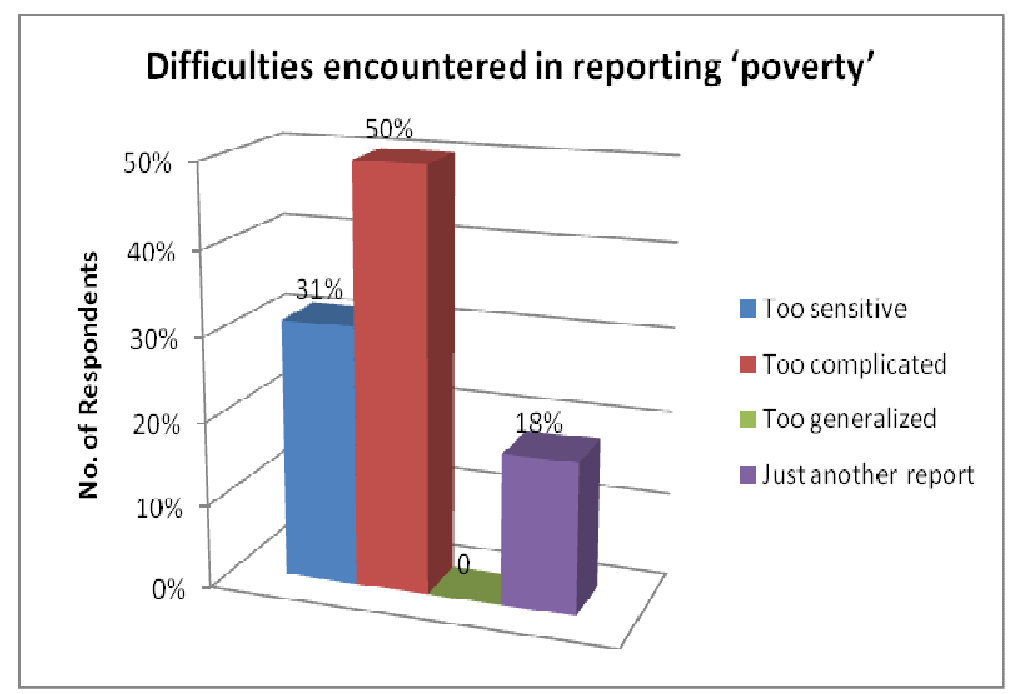

Figure XI

Figure XI reflects the responses that the respondents gave while trying to express the difficulties in reporting stories on poverty. $31 \%$ said that the stories on poverty are too sensitive, while $50 \%$ expressed that stories on poverty are too complicated. The other $18 \%$ felt that stories on poverty are just like any other stories.

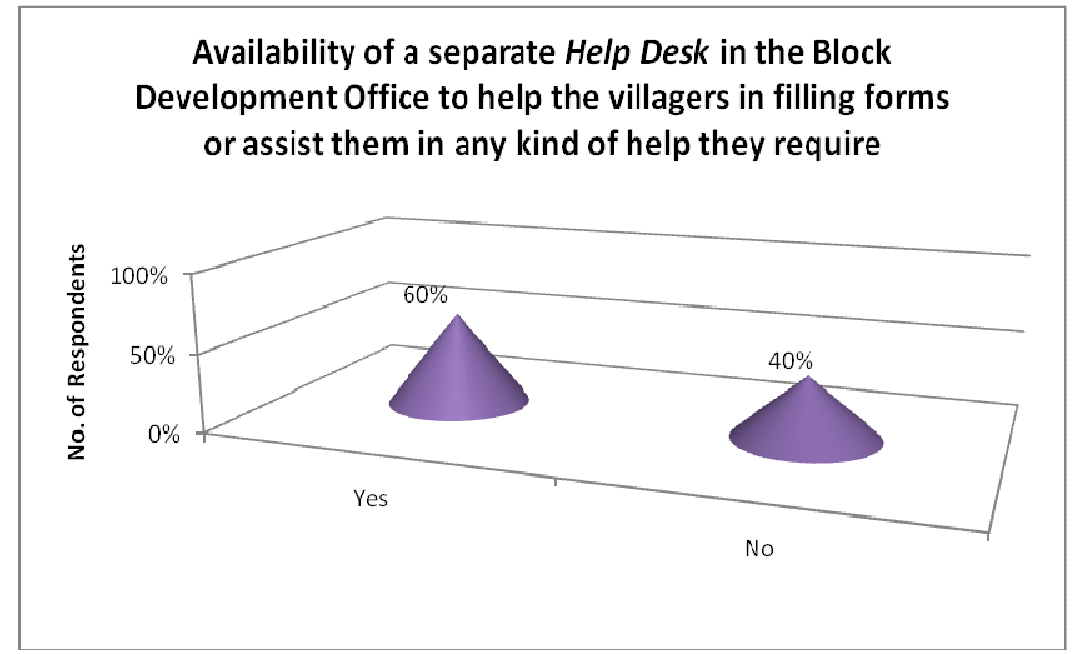

Figure XII

Figure XII shows the responses of the respondents from various Block Development Office on the availability of a Help Desk in their office. $60 \%$ of the respondents confirm that they have Help Desk. The other $40 \%$ said that they do not have such Help Desk in their office. The respondents have expressed that there is a need of such a help desk in the Block Development Office as this will help them to assist the rural masses better with any kind of queries that they might have.

\section{Responses: Expected Roles and Responsibilities of Media in Alleviating Economic Poverty}

The role of the media as mentioned previously is to a. to inform, b. to educate and c. to entertain. However, the findings in this research have confirmed that the media is expected to perform much more than expected in particular in its role to help alleviate economic poverty. To quote one of the respondents, the media should (Respondent 1, Print Media) “... draw the affection of government to the reasons for rural poverty and cite case studies in the report. Media should also 
bring to the public domain, gaps in implementation of various anti-poverty schemes". Adding to this, another respondent stated that the (Respondent 1, Electronic Media) "Media should disseminate the information on causes of poverty in a positive role. Programs highlighting rural poverty in simple, lucid and transparent manner in programs like a day in the village and moving across Meghalaya can go a long way in bringing focus to rural poverty”. The findings also indicated that the private channels (media) both print and electronic media can facilitate a lot of help delivering services while in the process of disseminating information to the people. This can be in terms of giving "Report to the public about current schemes and beneficial of the government. This help can also be sorted out by getting the outside support from NGO'S, village leaders, religious organizations and government functionaries" (Respondent 2 \& 3, Print Media).

The respondents have also come out strongly with a comment that the media should help (Respondent 4, Print Media) "By highlighting, the various problems focus of people below the poverty line. By pointing out at the loopholes in the implementation of various schemes and programmes for the poor and needy. By giving concrete suggestion to the Government for rectifying the lapses and deflects in the implementation of schemes".

\section{DISCUSSIONS}

A respondent in this research said (Respondent 1, Electronic Media) "Media should disseminate the information on causes of poverty in a positive role. Programs highlighting rural poverty in simple, lucid and transparent manner in programs like a day in the village and moving across Meghalaya can go a long way in bringing focus to rural poverty”. In a report on the record of PRSPs (poverty reduction strategy paper) and the role of communication within them, the first section of the report notes the changing policy approaches to poverty reduction and highlights the potential roles that the media could play. These include:

- Communicating with and informing a wide range of audiences on poverty reduction issues

- Providing an open forum to reflect different public views, including those of poor people

- $\quad$ Providing an inclusive platform for public debate

- Scrutinising and holding all actors to account for their actions, acting as a force for more transparent and accountable decision - making relevant to poverty reduction Panos London (2007).

The Dominant Paradigm observed that from a transmission / persuasion perspective, communication was understood as a linear, unidirectional process in which senders send information through media channels to receivers. Consequently, development, communication was equated with the massive introduction of media technologies to promote modernization, and the widespread adoption of the mass media (newspapers, radio, cinemas, and later television) was seen as pivotal for the effectiveness of communication interventions. The findings in this research reveal that the media houses in the State do not report much in the news about the occurrence of poverty (Figure II). While the reasons can be many, one prime reason is that the media is busy with reporting on other issues. In line with this finding, a news item mentions that in the Indian media, only the celebrities are important. If you are not famous enough, you say, your cause, and even your life have little news-value for the mainstream media (Talukdar, 2011).

However, keeping this as a top most priority, another data disclose that the media houses should consciously start addressing 'poverty' on a more regular basis and also start highlighting its causes (Figure III). These opinions of the respondents show clear expressions of the people on their expectations from the media and the belief that this medium can 
deliver. While emphasizing on the role of the media, the scale and insidious nature of poverty warrants new reporting approaches and strategies in order to prick the national conscience and prod governments into firmer action (Singh, 2011)

In its effort, the media have tried to cover quite a bit of such stories and news reports, but the structural causes of poverty, such as job loss, lack of economic opportunity, disability and analysis of the impact of government policy on poverty are often missing from the stories (Singh, 2011). Like many of the respondents agreed that 'Poverty' is a social issue that has been ignored for too long by the media (Figure IV).

When there is too much of emphasis that media has to do a lot, why then is media not meeting these demands. No doubt media channels have been doing their best and all that it can and is still striving. When asked what the reasons for the media to ignore poverty are, most agreed that it is not very much relevant for the readers (Figure V). Not many of the readers / viewers would be interested to read / view programmes / news on poverty. In fact, it has been identified as a part of the society. This is one reason why the masses are informed about government assistances, schemes and grants only sometimes by the media houses (Figure VI).

This research also found that the content for government assistance / grants advertisements are too vast to be portrayed in limited space or time (Figure VII), and for this reason, such announcements are announcing only on a convenient time and allotted space. This then leads to information being missed, especially on important matters (Figure VIII). Powerful media effects models suggested that there is a direct relation between the mass media and the masses and interpersonal relations were crucial in channelling and shaping opinion (Srampickal \& Aram, 2007). This insight was incorporated in diffusion studies, which proposed that both exposure to mass media and face-to-face interaction were necessary to induce effective change. This means to state that the effectiveness of field workers in transmitting information on agricultural development projects also suggested the importance of interpersonal networks in disseminating innovations (Waisbord, n.d.).

A group of working journalists in the State suggested that the media should create awareness programs, and make people aware of the schemes and loans being provided by the government. In addition the media should also highlight the needs of the poor. The findings also confirm that the media should help:

- "By highlighting, the various problems focus of people below the poverty line."

- "By pointing out at the loopholes in the implementation of various schemes and programmes for the poor and needy."

- "By giving concrete suggestion to the Government for rectifying the lapses and deflects in the implementation of schemes." (Respondent 1, Print Media)

These working professionals are consciously aware of its role and states that they do not encounter much difficulty while reporting news on poverty (Figure X). However, they also identified that they find it difficult in allotting space for information on the availability of loans / subsidies and government monetary benefits, to the masses through their media houses (Figure IX). This could be due to the maximum spaces being allotted to heavily paid advertisements from private firms and companies. The bridge that needs to be build here is to necessitate the need to equally give due preferences to such imporatnt ads, and to focus on the penetration of information to the masses on such announcements.

In trying to address this issue, an effort has been initiated by the government (Figure XII) to provide a separate 
Help Desk in the Block Development Office to help the villagers in filling forms, or assist them in any kind of help they require, in relation to applying government schemes and grants. Along with this, today the government has different websites and call centres that provide instant information or answers queries to questions of development.

This effort seems to be going into the right track because right from its inception, development, communication has been pursued by all kinds of media, both traditional and new to help fill this gap of assisting and informing. However, sadly enough, it had been put into more theoretical use as its possibilities, people's change of demand and opportunities have not been used to its limit to get an overall success (Choudhury, 2011).

The communication needs as identified by UNESCO in the "New Paradigm" are open dialogue which reflects diversified views and experiences. Secondly, multi directional communication flow is necessary. This multi directional flow calls for top down as well as horizontal communication and bottom-up communication. The horizontal communication is across society, horizontally - from person to person, village to village and rural to urban (Kumar, 2011).

In identifying media's role, UNESCO further contends that for participatory rural communication, media should be made available in rural areas. There should be linkage between development initiatives and communication channels. This was much expressed by the respondents when stated that the media should "Report to the public about current schemes and beneficial from the government. This help can also be sorted out by getting the outside support from NGO'S, village leaders, religious organizations and government functionaries" (Respondent $2 \& 3$, Print Media).

\section{CONCLUSIONS}

Using multiple approaches, both qualitative and quantitative, this research has attempted to describe the effectiveness of using media channels to reduce economic poverty in Meghalaya. The literature revealed that economic poverty has been exciting in the State for a long time, and studies has been conducted to analyze its prevalence and how to reduce it.

In this research, when enquired about the causes of economic poverty in the State, there were a lot of known and unknown reasons that came into the surface; some came as the major cause, while others as minor cause. An attentiongrabbing finding in this research shows that one of the main causes of economic poverty in the State is inaccessibility of roads to all the Blocks, Districts and interior most villages. However, it will be interesting to note that in the entire survey conducted during the research, not even a single respondent consciously stated that one of the major causes of economic poverty is inaccessibility to proper roads in their respective areas. This research also identified the deficiencies or lacunae of media's effectiveness to reach its target audience, placed at different geographical terrain, which has failed miserably over the past many years, though a lot of effort is put into improving this process till date. Hence, it may be concluded that poverty in communication is the root cause of economic poverty. Economic poverty is a web and when caught in this vicious circle, the shortcoming of one basic facility handicaps other facilities in a person's life. The rural populace fails to understand that education is a must for people to get out of the trap of poverty. Education was never given due importance.

Media channels could have a far better coverage even to the most interiors of the State through proper planning and implementation. And in doing so, area identification and specification of required programmes should be part of the planning process. Language is a barrier if the message and information are not understood by all the recipients of the message.

Timing was also found to be a hindrance, as any program that is given after the people leaves for their farms and 
paddy fields, are missing and in most cases, necessary information does not reach them. Media channels are looked up as sources of connectivity to the outer world, a medium of entertainment, the only tool where people can stay informed on all important events and messages on developmental issues. This research indicates that newspapers, for instance, reach some villages only after two days of publication, depending upon the schedule of the busses that ply those areas. Distance has been the main barrier for all necessary information to reach the people. The groups that are more advantageous to enjoy the government facilities are those who are near to the Blocks while the villages that are placed very far away are sidelined and lose all the benefits and information. As such, distance should be a top priority that should be incorporated in media planning.

In the process of improving economic development among the rural masses, the media has been identified as a powerful tool to help address it. For those who rightly used the media channels, they confirmed that the media channels have facilitated the rural people with updated news and relevant information which have improved their daily lives. In this research, media's penetration was found to be limited because of numerous reasons and because of these gaps; the efforts of the government are left half-baked. Messages on government assistances in particular reach the public in bits and pieces leaving them to miss out on many schemes, grants, subsidies and benefits.

It was found that people's choice of viewing, listening and listening habits diverts their focus from being exposed to important announcements and information. It may also be concluded that the habit of media choice depends largely on the age group of the audience. As such, these various age categories show interest in certain topics, issues and agendas related to their careers, livelihoods and personal lives and benefits coming from external bodies. The media channels which include radio, TV, mobile phones and the newspapers have shown a tremendous impact to its users where they confirmed that they have largely benefitted from its usage over the years. But what is important to note in this finding is that exposure also comes with attitudinal and behavioural change. Awareness and well informed individuals are also the ones claiming that they have got government assistances, and they have also helped in providing guidance to neighbours, friends and relatives.

While a finding in this research reveals that the media has been ignoring poverty for too long, it may also be concluded that media's role in projecting and highlighting government's assistance to help alleviate economic poverty in the State is a highly conscious elucidation endorsed by all. These included the respondents and in particular representatives of various media houses, working journalist and reporters. Some of the key suggestions on media's role are to communicate and inform a wide range of audiences on poverty reduction issues, providing an open forum to reflect different public views, including those of poor people and act as a force for more transparent and accountable decisionmaking relevant to poverty reduction.

This study confirms that the media do not give due coverage to news on the occurrence of poverty in Meghalaya State and as a solution to sort this issue, the findings states that the media should consciously start addressing poverty on a more regular basis and also start highlighting its causes. The findings also show that the people in general expect a lot from the media in terms of delivery, dissemination of messages and a linked between the poor and the government.

There are many reasons for media's inability to do coverage on poverty related issues, and gaps have been identified which needs to be addressed. Respondents not being able to interpret the content of the message, limited allocation of space in media channels and poverty issues being very sensitive and confusing were shielded as the main reasons besides others. In the process of addressing these issues, pre planning involving the government, media houses and 
the beneficiaries' needs to be taken into account to collectively find a permanent solution to help bridge these gaps.

\section{REFERENCES}

1. Choudhury, P. S. (2011). Media in Development Communication. Global Media Journal - Indian Edition; Dec 2011, Vol. 2 Issue 2

2. Gopalakrishnan, R. (1995). Meghalaya Land and People. New Delhi, Omsons Publications

3. Government of India, Planning Commission, (June, 2014), Report Of The Expert Group To Review The Methodology for Measurement of Poverty

4. Joseph, A. (2011). The media as watchdog. Is anyone watching poverty? Challenges to Poverty Reporting In India, Editor, Samuel W. Meshack, Printing Coordination: Peter Publishers, Published by Gurukul Lutheran Theological College and Research Institute for WACC - Asia Region

5. Katju, M. (2011 November 5), "The Role the Media should be playing in India". The Hindu

6. Katju, M. (2008, August 19), "Ideal and reality: media's role in India", The Hindu

7. Kumar, R. (2011) Development Communication: A Purposive Communication with Social Conscience - An Indian Perspective, Global Media Journal - Indian Edition; Dec 2011, Vol. 2 Issue 2

8. Meshack, W. S. (2011). Challenges to Poverty Reporting In India. Printing coordination: Peter Publishers, Published by Gurukul Lutheran Theological College and Research Institute for World Association for Christian Communication - Asia Region

9. My India: History of Meghalaya (2012). Viewed on January 26, 2014, 05:20 pm, http://gopalakri.blogspot.in/search?updatedmax $=2012-11-27 T 20: 00: 00-08: 00 \&$ max -results $=1$ \& reverse-paginate $=$ true \& start $=2 \& b y$-date $=$ false

10. Nayak, P. Thomas, E.D (2007). Human Development and Deprivation in Meghalaya. New Delhi-110002, Akansha Publishing House, Delhi

11. Panos London (2007), "Making poverty the story: Time to involve the media in poverty reduction" Panos London, September 2007, Panos London, 9 White Lion Street, London N1 9PD, United Kingdom

12. Poverty Alleviation in Rural India: Programmes and Strategy. (2002), Ninth Five Year Plan (Vol 2).

13. Raghavan, G.N.S (2005). Development and Communication in India (Elitist Growth and Mass Deprivation). New Delhi110002, Gyan Publishing House, Delhi

14. Saxena, C. N. (2003). Rural Poverty in Meghalaya: Its nature, dimensions and possible options, Planning Commission, Government of Meghalaya

15. Shakeel, M. K. (2012, December). "The role of media in today's world" Hamari Web Articles

16. Srampickal, J. Aram, A. (2007). Understanding Development Communication. From modernization theory to participation and empowerment with an emphasis on cultural aspect in development. Published by Media House, Delhi

17. Singh, S (2011, October 13) "Role of news media in poverty reduction efforts" Solomon Star, Solomon Islands Leading Daily Newspaper

18. Talukdar, S. R. (2011, June 26). "Media's obsession with celebrities and ignorance of common people"

19. "Rural people unaware of Central Schemes" (2011, July 17) The Shillong Times, Established 1945, Retrieved on January, 21, 2014 from http://www.theshillongtimes.com/about-us 
20. "Poverty up in Meghalaya: Plan panel report" (2012, March 20). The Shillong Times, Established 1945, Retrieved on May 8, 2014 from http://www.theshillongtimes.com/about-us

21. Thomas, E. D. (2004). Poverty and Rural Development in Meghalaya (India). New Delhi-110059, Akansha Publishing, Delhi

22. Waisbord, Silvio (n.d.). Family Tree of Theories, Methodologies and Strategies in Development Communication, Prepared for the Rockefeller Foundation

23. Yadav, S. (2014). Culture of Corruption in India, First Edition, Publisher Orient Waterman 